\title{
MulTimedia LEARNing: AN ACTIVITY BASEd COMPUTER TO DEVELOP READING COMPREHENSION
}

\author{
Endang Sulistianingsih, Fajar Prihatin, Sri Mulyati \\ Department of English Education and Department of Indonesian Education, Universitas Pancasakti Tegal
}

endang.sulistia@gmail.com, fprihatin@gmail.com, srimulyati@gmail.com

\begin{abstract}
The aimed of the study was to find out the effectively of multimedia learning as an activity-based computer to develop reading comprehension. The students' comprehension development is crucial to help students to be successful in following development of science and technology, since most of the scientific works are released in English. This research used experimental design with pre-test and posttest one design. There were 47 students as participants. The pre-test was done to test the sample similarity and the initial level of student's reading comprehension. The movies were shown during the intervention session. Then the evaluation and post-test were done to find out the student's reading comprehension development. Hypothesis was tested using t-test. The result indicated that multimedia learning as an activity-based computer was effective to develop student's reading comprehension.
\end{abstract}

Keywords: Multimedia, Computer, Reading Comprehension, CALL, EFL learner

\section{INTRODUCTION}

English is crucial to be mastered for students because most of the academic's books, research journals and technology are written in English. Through good proficiency in English, the students will not face difficulties when they have to read English literature books. Reading can be done trough many contexts, and sometimes the important thing is only the skill in interpreting the text into meaningful one. The matter is when someone is expected to read in a certain context i.e. academics context as a part of learning (Grabe, 2009). Braguglia, (2005) says that reading is needed to achieve academic success and intellectual development. Reading skill is a complex process done by the students to comprehend ideas, minds and experience to interact and communicate.

Based on the interview, the students feel that comprehending a text especially English text is not easy since it is difficult to comprehend the text in different languages. Reading is a thinking and interaction process, thus to develop students' reading comprehension needs continuous exercises. And those exercises should be supported by a learning activity which is essential for students' needs. One of the learning approaches to develop student's reading comprehension is learning activity- based multimedia.

The term multimedia firstly introduced by Clark \& Paivio, (1991) evealed that information in verbal memory and visual memory preserved were preserved better than only in one memory system. Giving pictures to text or narration provides initial learning of the concepts, and retention as long as they are supported each other and focused in instructional learning (Mayer \& Moreno, 2003). In other words, multimedia is the use of some media combination to provide the information. These combinations can consist of texts, graphics, pictures, videos and interactive speeches or sound. Some previous studies have revealed multimedia learning gives good effect on reading comprehension (Chun \& Plass, 1996; Hanley, Herron, \& Cole, 1995; Huang, 2014; Sherwood, Kinzer, Hasselbring, \& Bransford, 1987). The recent technology makes teachers and students integrate, combine and interact with the media (Ivers \& Barron, 1998). All these previous studies are conducted in the context that English is the first language (L1) of the participants, the present study involves an EFL learners as a participant where the proficiency level of the participants is not the same. This present study is intended to find out the effectiveness of multimedia learning as an activity based computer to develop reading comprehension specially for EFL learners where the participants' proficiency varies. 


\section{MATERIALS AND METHOD}

This study used one group pre-test post-test design. The participants were 47 students of second semester of English education department. The multimedia learning was employed in reading for general purposes 2 class. The participants were English Foreign Learners where the proficiency level were not the same. In this study there was only one control group (before intervention) and experimental group (after intervention). Data obtained before intervention were control group data and data obtained after intervention were experimental group data. Data from control group was pre-test and experimental group was post-test. The data were gained from IELTS reading test consisting of 40 questions.

The intervention was done through watching interactively the media from the channel in YouTube. The students chose their materials based on their interest. The materials were in the multimedia or the integrated of digital sound, image, text and video components form trough computer. The materials were from many kinds of topics from various channels, i.e. learning English through story, national geographic, science and discovery. The intervention was given once a week with the duration of 100 minutes. The students were asked to make a group then they chose their material, and they presented that material in front of the class. After the material was presented then they run the discussion interactively.

\section{RESULTS AND DISCUSSION}

The pre-test data were from one instrument and that were IELTS reading test consisted of 40 questions. The pre-test were gained before the intervention, Table 1 indicated the result of Pre-test distribution frequency and Table 2 shows the distribution of pre-test score.

Table 1

Pre-test Distribution Frequency

\begin{tabular}{lll}
\hline $\mathrm{N}$ & Valid & 47 \\
& Missing & 0 \\
Mean & & 60,2021 \\
Minimum & 40,0 \\
Maximum & 80,0 \\
\hline
\end{tabular}

Table 2

Pre-test Distribution Score

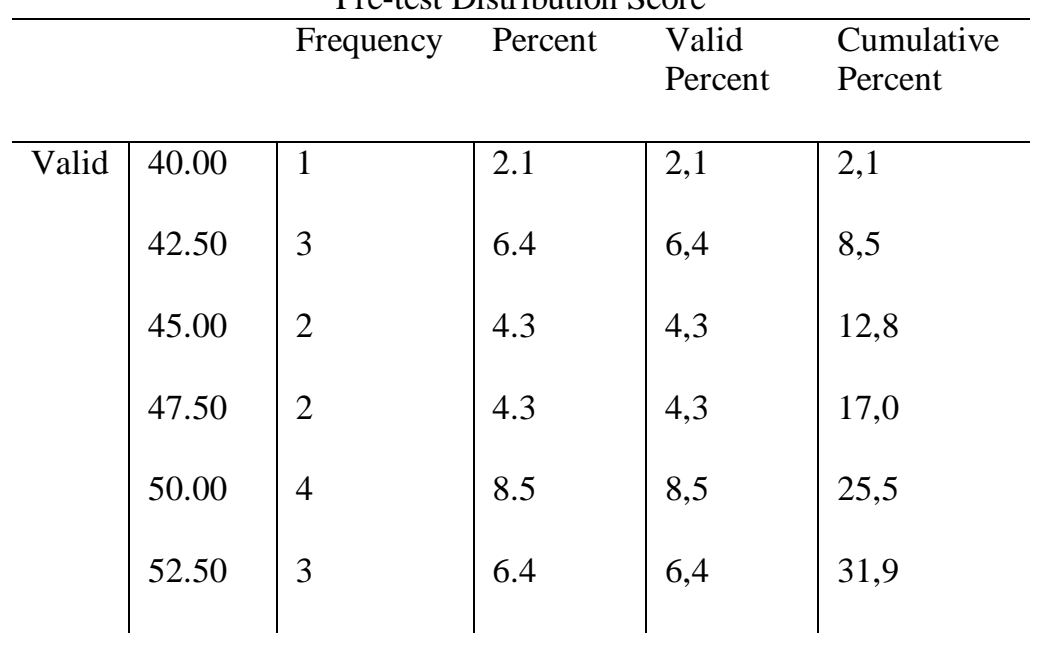




\begin{tabular}{|l|l|l|l|l}
55.00 & 2 & 4.3 & 4.3 & 36.2 \\
58.00 & 2 & 4.3 & 4.3 & 40.4 \\
60.00 & 2 & 4.3 & 4.3 & 44.7 \\
62.50 & 2 & 4.3 & 4.3 & 48.9 \\
63.00 & 3 & 6.4 & 6.4 & 55.3 \\
65.00 & 3 & 6.4 & 6.4 & 61.7 \\
67.50 & 4 & 8.5 & 8.5 & 70.2 \\
68.00 & 4 & 8.5 & 8.5 & 78.7 \\
70.00 & 6 & 12.8 & 12.8 & 91.5 \\
72.50 & 1 & 2.1 & 2.1 & 93.6 \\
75.00 & 2 & 4.3 & 4.3 & 97.9 \\
80.00 & 1 & 2.1 & 2.1 & 100.0 \\
Total & 47 & 100.0 & 100.0 & \\
\hline
\end{tabular}

Table 2 indicated that the lowest score was 40 and the highest was 80 . The total data was 47 and the mean was 60.20. Post-test data was from multiple choice that was given after the treatment, and the result was at table 3.

Table 3

Post-test Data Distribution Frequency

\begin{tabular}{lll}
\hline $\mathrm{N}$ & Valid & 47 \\
& Missing & 0 \\
Mean & & 79.2766 \\
Minimum & & 50.0 \\
Maximum & & 95.0 \\
& & \\
\hline
\end{tabular}

Table 4

Post-test Distribution Score

\begin{tabular}{|c|c|c|c|c|c|}
\hline & & Frequency & Percent & $\begin{array}{l}\text { Valid } \\
\text { Percent }\end{array}$ & $\begin{array}{l}\text { Cumulative } \\
\text { Percent }\end{array}$ \\
\hline Valid & $\begin{array}{l}50.00 \\
57.50\end{array}$ & $\begin{array}{l}1 \\
1\end{array}$ & $\begin{array}{l}2.1 \\
2.1\end{array}$ & $\begin{array}{l}2,1 \\
6,4\end{array}$ & $\begin{array}{l}2,1 \\
8,5\end{array}$ \\
\hline
\end{tabular}




\begin{tabular}{|l|l|l|l|l}
62.50 & 1 & 2.1 & 4,3 & 12,8 \\
65.00 & 2 & 4.3 & 4,3 & 17,0 \\
67.50 & 5 & 10.6 & 8,5 & 25,5 \\
70.00 & 2 & 4.3 & 6,4 & 31,9 \\
75.00 & 4 & 8.5 & 4.3 & 36.2 \\
77.00 & 2 & 4.3 & 4.3 & 40.4 \\
80.00 & 2 & 4.3 & 4.3 & 44.7 \\
82.50 & 1 & 4.3 & 4.3 & 48.9 \\
83.00 & 7 & 6.4 & 6.4 & 55.3 \\
85.00 & 6 & 6.4 & 6.4 & 61.7 \\
87.50 & 5 & 8.5 & 8.5 & 70.2 \\
88.00 & 2 & 8.5 & 8.5 & 78.7 \\
90.00 & 4 & 12.8 & 12.8 & 91.5 \\
92.50 & 1 & 2.1 & 2.1 & 93.6 \\
95.00 & 1 & 4.3 & 4.3 & 97.9 \\
Total & 47 & 100.0 & 100.0 & \\
\hline
\end{tabular}

Table 4 indicated post-test distribution score. The lowest score was 50 and the highest was 95 . The average of student's score was 79.28. Based on the data, there was an increase in average score before and after the intervention was given. In other words, the multimedia learning model was effective to develop students' reading comprehension. In addition, to see the significance of pre-test and post-test we use SPSS and the result was shown on Table 5.

Table 5

Paired Samples Test

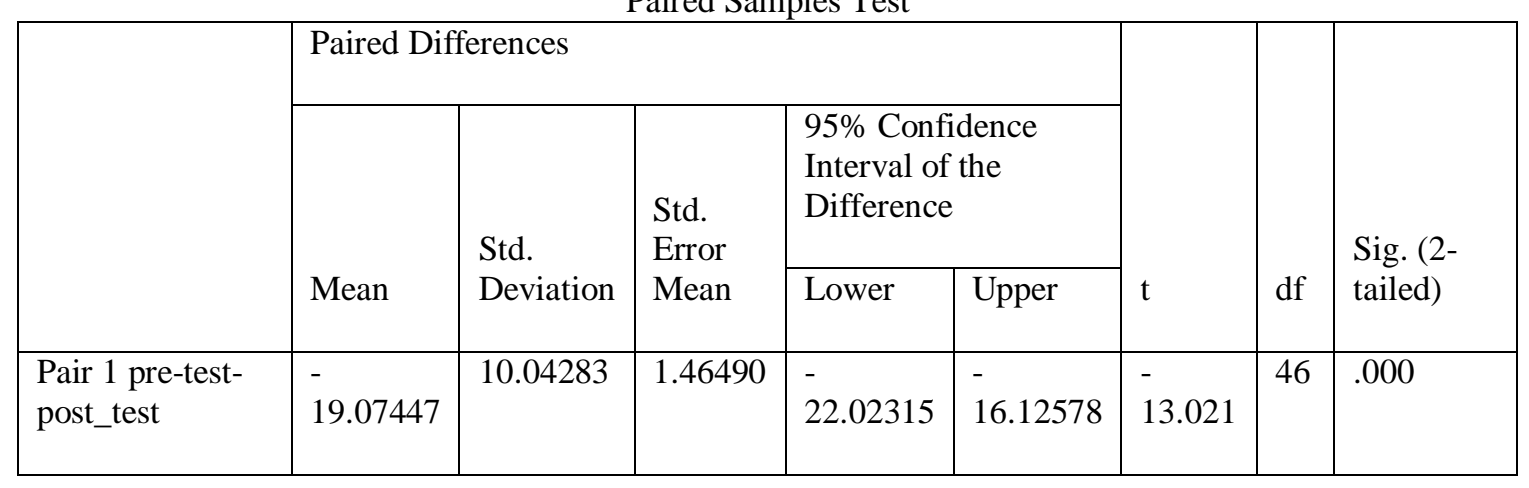


Table 5 showed that the significant value was 0.000 of $5 \%$ significance. This mean that there was significant difference before and after the multimedia learning model was applied. The use of multimedia learning as an activity based computer was one of the way to develop students' reading comprehension. The use of multimedia gave many benefits, such as the learning process became more effective, efficient and attractive. Based on the observation during the intervention, the use of multimedia could assist in developing comprehension, serving appealing data, informative and interactive, and facilittate data interpretation.

\section{CONCLUSION}

The result of the study indicated that multimedia as a learning based computer is effective to develop students' reading comprehension. It is also found that the use of multimedia as a learning based computer gives some benefits such as: the learning process in time and placess is more effective and efficinet, the students feel more interesting and not bored anymore, the materials given to students is easier to be conveyed. In addition, the study also finds that the multimedia as learning based computer help them to develop their comprehension since the data and information are informed in a such attractive form, informative and interactive so that it is easier for them to interpret the data and information conveyed.

Reading is a very crucial skill since it is as an literacy input for students, and it is influenced of student's success. Reading concerning to a meaning making procees is not an easy activity since it is considered as a complex process in comprehending ideas, experience and reflexion as a whole. During the intervention process the students prefer to use video as a source of their reading text materials, and in this case they are not only as participant but also as an active readers. The students develop into well motivated readers since they can choose their own story or materials and it is freely downloaded from internet. The combination of audio and picture in video makes the students feel interesting and enthusias in doing reading activity. This study contribute for educators insight in developing student's literacy.

\section{ACKNOWLEDGEMENTS}

This research is funded by Ministry of Research, Technology and Higher Education of the Republic of Indonesia trough research grant of "Penelitian Dosen Pemula".

\section{REFERENCES}

Braguglia, K. H. (2005). Reading habits of business students. Journal of College Teaching \& Learning, 2(3), 67-72.

Chun, D. M., \& Plass, J. L. (1996). Facilitating reading comprehension with multimedia. System, 24(4), 503-519.

Clark, J. M., \& Paivio, A. (1991). Dual coding theory and education. Educational Psychology Review, 3(3), 149-210.

Grabe, W. (2009). Reading in a second language: Moving from theory to practice. Ernst Klett Sprachen.

Hanley, J. E. B., Herron, C. A., \& Cole, S. P. (1995). Using video as an advance organizer to a written passage in the FLES classroom. The Modern Language Journal, 79(1), 57-66.

Huang, W.-C. (2014). The effects of multimedia annotation and summary writing on Taiwanese EFL students' reading comprehension. Reading, 14(1).

Ivers, K. S., \& Barron, A. E. (1998). Multimedia projects in education: Designing, producing, and assessing. Libraries Unlimited Englewood, CO.

Mayer, R. E., \& Moreno, R. (2003). Nine ways to reduce cognitive load in multimedia learning. Journal of Educational Psychology. https://doi.org/10.1207/S15326985EP3801_6 
Sherwood, R. D., Kinzer, C. K., Hasselbring, T. S., \& Bransford, J. D. (1987). Macro-contexts for learning: Initial findings and issues. Applied Cognitive Psychology, 1(2), 93-108. 